\title{
THE MULTIPLE DATA AND GEOGRAPHIC KNOWLEDGE APPROACH TO A LIQUID TOXIC ROAD ACCIDENT MITIGATION - TWO BLOCK GIS DATA PROCESSING FOR AN OPERATIVE INTERVENTION
}

\author{
Jaromír KOLEJKA ${ }^{1}$, Petr RAPANT ${ }^{2}$, Jana ZAPLETALOVÁ1
}

DOI: 10.21163/GT_2019. 141.04

\begin{abstract}
:
One of the current tasks of disaster management is to effectively counter toxic accidents on traffic communications. The paper demonstrates the procedure of the use of geographic data and knowledge with GIS technology for the operational mitigation of accident impacts on the traffic communication with leakage of toxic substance. A simulated leakage of toxic liquid substance on a highway in the Czech Republic was chosen as an example.

The process is divided into two units. In the first preparatory block, data on soils and the geological environment are analysed and purpose oriented pre-processed. The data layer generally describes the expected movement of pollutants, e.g. predominant surface runoff, or predominant infiltration and/or a balanced combination of both of them. In the second operational unit, a location of the accident is precisely identified and the estimation of possible routes of pollutant runoff is performed with respect to the current status of the territory. Key points on these routes are identified with the aim to select mitigation measures and optimum access routes modelled for intervention techniques to reach key points in order to prevent contamination of water bodies.
\end{abstract}

Keywords: Data pre-processing, Operational data processing, GIS, Routes of pollutant run-off, critical points, best access routes, risk management.

\section{INTRODUCTION}

The leakage of toxic or other harmful substances occurs on roads and rails very often. On roads rather more numerous leakages can be expected, due to the nature of road freight transport (the capacity of each lorry) being predominant in smaller volumes than on railways. On the other hand, the roads usually go much closer to places where there is a permanent or occasional concentration of population potentially threatened by accidents related to the leakage of harmful substances.

Risk categorisation of roads and highways of the Czech Republic using statistically registered accidents was carried out under the European programme of assessing the safety of roads EuroRAP (European Road Assessment Programme) (EuroRAP is an international non-profit organisation founded in 2003 in Belgium, whose members are motoring associations, national and regional administrators of roads and investors, invited experts and commercial organisations). According to these statistics, motorways and expressways seem to be the safest roads. Media information, however, gives the impression that the most

\footnotetext{
${ }^{1}$ Institute of Geonics, Czech Academy of Science, Ostrava, Department of Environmental geography, Drobného 28, CZ-60200 Brno, Czech Republic, jkolejka@centrum.cz, jana.zapletalova@ugn.cas.cz.

2 VSB-Technical University of Ostrava, Faculty of Mining and Geology, Department of Geoinformatics, 17. Listopadu 2172/15, CZ-70800 Ostrava-Poruba, Czech Republic, petr.rapant@vsb.cz
} 
serious accidents occur mainly on motorways, where these events are greatly mediated. Strictly speaking, it is obvious that such accidents can happen anywhere where hazardous substances are transported by road or by railway. So, such events are of greater amounts there and the number of potential sites of their creation is endless. Research teams are trying (with the assistance of modern information technology) to construct standardised procedures to streamline remediation post emergency interventions in the field. Yet, of course, it is impossible to prepare an exhaustive number of accident scenarios that, despite using scientific knowledge and available geospatial technologies, would cover all possible locations. The standardised scenario must therefore be formulated in such a way that it could be started when the disaster management staff receives the information about such an incident. This paper aims to demonstrate the procedure for completing such a scenario using GIS technology on the example of a simulated accident on a highway, and to demonstrate its applicability under specific long-term and short-term territory conditions.

\section{THEORETICAL AND METHODOLOGICAL BACKGROUND}

The ADR Decree (European Agreement Concerning the International Carriage of Dangerous Goods by Road) sets out the general conditions for the transportation of dangerous substances on the roads. Its revised version came into force in the EU member states in January 1, 2015. The methodology and proposed procedures dealing with the risks of possible consequences of accidents in the transport of dangerous substances by road are based on this directive. Generally, transportation of hazardous and toxic substances is regulated by international legislation, which is based on EU Regulations (RID, ADR, ICAO, ADN, IMDG Code). General principles for transporting dangerous materials are common to all transport modes of such substances. Their dangerousness is given by their physical-chemical properties, toxicity or ecotoxicity. A number of different methods and studies dealing with the transportation of hazardous substances show that the transport of hazardous substances is a very relevant topic for today. As shown by the statistics, $39 \%$ of all toxic accidents occur during transportation and another $8 \%$ during loading and unloading (Bernartík, 2006). For example, in Italy, the calculation of the risk of accidents during transport of these substances was done by Fabiano, Currò, Palazzi, \& Pastorino (2002).

Light fuel oils (LPG), gasoline, diesel, chlorine, ammonia and other industrial gases are transported in the Czech Republic on roads. Among accidents of vehicles carrying toxic substances generally prevail the accidents of liquid substances (Chudová \& Blažková, 2007). The calculation of the risk of accidents when carrying dangerous substances was done in many countries, including the Czech Republic (Krejčí \& Bambušek, 2012). The authors use data from the National traffic census and statistical data. They state that 1,669 million tkm of dangerous goods were transported on roads in the Czech Republic in 2010. 101 traffic accidents of vehicles carrying hazardous materials were reported for the same year (Krejčí \& Bambušek, 2012).

The key work dealing with the research into toxic accidents on roads is represented by the Guidelines for quantitative risk assessment (Purple Book) (De Haag \& Ale, 2005) which, in its second part, deals with risk evaluation of hazardous substances transportation. A quantitative risk assessment approach of the transport of dangerous substances is also referred to in a complex view by Nicolet-Monnier \& Gheorghe (1996). They formulate their ideas applying existing knowledge to meet the needs of risk management. Нøj \& Kröger (2002) conducted a risk analysis of transport (in general, not just hazardous 
substances) on roads and rails. They noted that the risk assessment was mostly devoted to special sites on the transport network, such as tunnels or bridges. The issue of risk in tunnels is also addressed by Diamantidis, Zuccarelli \& Westhäuser (2000). They sorted out the obtained and reviewed documents from specific events in the form of guidelines for decision making processes and they also elaborated thematic terminology suitable for communication among experts of risk management. Some works indicate the need to standardise procedures for disaster management (Fabiano et al, 2002).

Goerlandt \& Montewka (2015) note that the number of applications designed for risk management does not take into account the theoretical issues related to crisis management (e.g., set of definitions and terminology or perspectives of risk). This can cause a number of problems. The behaviour of people in disastrous situations has an individual character, but it demonstrates many common features (Burns \& Slovic 2012; Fujiki \& Renard, 2018). The vulnerability of densely settled urban areas to technological risks is especially very complex (Ştefănescu, Botezan \& Crăciun, 2018). The behaviour of certain persons can even be predicted in specific situations (De Dominics et al, 2015). In view of this, it is necessary to create and search for appropriate forms of warning in the event of a crisis situation, in order to prevent additional damage. From a practical point of view (with regard to the unpredictable part of human behaviour), the construction of mitigation scenarios for road toxic accidents must be formulated so as to minimise the extent of the threat at the outset through the use of equipment and professional rescue teams.

Considerable attention is devoted to risk assessment of accidents with leakage of hazardous substances and the use of GIS tools in the professional community. Using GIS tools, it is possible to describe, visualise and model the past and ongoing emergencies, including accidents on the roads (Zhang, Hodgson \& Erkut, 2000). There is a wide spectrum of GIS studies dealing with the issue of toxic accidents on roads ranging from the optimisation of transport routes of hazardous substances in order to minimise the risk of accidents and minimisation of negative impacts on the environment, through the studies modelling course of events, and designing effective intervention after the mitigation and elimination of the impact of the accident. Kolejka (2010) looked into the localisation of key areas for intervention units in case of leakage of liquid toxic substances in urban environments. Bubbico, Di Cave \& Mazzarotta (2004) used data on the population, the local environment and the current meteorological situation for evaluating the risk of potential toxic accidents and the need for effective intervention. A GIS-based study dealing with the risk of hazardous material transportation on roads was completed by Huang (2004) as an example of the type of frequented use of GIS technologies in the risk assessment of transport on roads. Questions of the organisation of evacuations of endangered persons by means of decision-making support systems (DSS) based on GIS were dealt with by de Silva $\&$ Eglese (2000). The studies dealing with intentional toxic accidents on roads as terrorist acts are also included (Maschio et al, 2009). A part of the evaluation of the risk of transport of hazardous substances may be represented by visualisation of such risks. Van Raemdonck et al, (2013) highlight this on the example of Flanders. Their work focuses on two components: a) assessment of the probability of an accident, and b) the evaluation of consequences of an accident (if it occurs). A similar method was also used by Verma \& Verter (2007). Risk prevention and effective elimination of the consequences of accidents can be crucial especially in the transport of hazardous (toxic) substances. Cadar, Boitor \& Dumitrescu (2017) confirmed that an increase in the Annual Average Daily Traffic 
(AADT) generates an increase in the total number of road accidents. Ivan \& Haidu (2012) documented the time concentrations of road accidents in rush hours.

Many programmes for risk modelling associated with toxic accidents were developed. These include, e.g., the programmes PHAST, RMP COMP, ALOHA, CHARM, EFFECTS, ROZEX and others. The CAMEO programme and the subsequent mapping software MARPLOT (Mapping Application for Response, Planning and Local Operational Tasks) was developed for dispersion modelling of hazardous substances. It was developed by the United States Environmental Protection Agency (EPA) and the National Oceanic and Atmospheric Administration (NOAA). In the Czech Republic, the software ROZEX alarm has been developed (http://www.tlp-emergency.com/rozex.html). It is an application enabling model leakage of dangerous chemical substances, quickly generating the necessary information for the intervening bodies of the Integrated Rescue System. Besides the characteristics of hazardous chemicals, the programme works also with GIS systems and enables dangerous zones in the map layer to be depicted.

The frequency of transport of dangerous goods is permanently increasing. Its growth is mainly due to the globalisation of industrial production. Especially the transfer of freight from rail to roads is very strongly manifested. It is generally estimated that about $20 \%$ of vehicles transport hazardous or toxic substances. Such an accident, depending on the nature of the accident site and the transported hazardous or toxic substances, can directly threaten the inhabitants in settlements, as well as waterways, soils and underground waters. The consequences of accidents of trucks transporting fuel are especially dangerous. Usually the point is that several tens of tons of fuel may escape into the surrounding environment. The worst accidents are in the settlements, where the spilled fuel may leak into the sewage system. Its evaporation causes high concentrations of flammable gases that spread in sewers, uncontrollably explode and cause subsequent fires (e.g. Sydney 1987 - see Tuma, 2000).

The essential condition for quick implementation of efficient scenarios for optimising intervention after the occurrence of the event is represented by the access to publicly available data, GIS technology, quality and reliable functioning communication between the disaster management staff and field intervention unit. The below presented procedure is a concise and revised version of the detailed user manual published in book form in 2015 (Kolejka, Rapant et al, 2015). The preliminary research results were demonstrated to the scientific community at a conference in Brno, Czech Republic in 2015 (Kolejka, Rapant, Zapletalová, 2016).

\section{THE OPTIMISING SCENARIO FOR FIELD INTERVENTION AFTER A TOXIC DISASTER ON THE ROAD}

\subsection{Data sources}

The accident on a road connected with leakage of harmful (toxic) substances (in this case liquid) should be viewed from two standpoints:

1. The event occurred in a particular area, whose features have an effect both on the spread of liquid pollutants into the area and on the accessibility of suitable intervention sites available for the technique.

2. The event occurred at a specific moment of time, which corresponds to the timevarying features of the territory. 
Taking these facts into account, it is necessary to divide the mitigation procedure into two working units:

A - Preparatory block, during which time conventionally constant data about the territory will be collected, evaluated and processed for future operational application. The purpose of the process is to create data layers representing potential conditions for the movement of liquid pollutants in the area in compliance with realistic, time-varying area features at the moment of accident.

B - Operational block, whose activity is started after the emergency staff receive information about the disaster. Now, the prearranged data from the preparatory block are used in the context of current conditions of the area, both positional and instantaneous. Data sources concerning the stable features of the territory and having an influence on the behaviour of liquid pollutants are listed in Table 1.

Table 1

Data sources for use in preparatory and operational blocks for supporting crisis management in response to a toxic disaster on the road

\begin{tabular}{|c|c|c|c|c|}
\hline No. & $\begin{array}{c}\text { branch of } \\
\text { knowledge }\end{array}$ & $\begin{array}{l}\text { title of } \\
\text { geodata }\end{array}$ & administrator & \begin{tabular}{|l} 
data contents and method of \\
application
\end{tabular} \\
\hline \multicolumn{5}{|c|}{ Preparatory block } \\
\hline 1 & geology & $\begin{array}{l}\text { Geological } \\
\text { map of ČR } \\
50\end{array}$ & $\begin{array}{l}\text { CGS } \\
\text { (Czech Geological } \\
\text { Survey) }\end{array}$ & $\begin{array}{l}\text { The digital map is available at a } \\
\text { resolution corresponding to the scale } \\
\text { of } 1: 50000 \text {, even though it was } \\
\text { apparently constructed (before } \\
\text { generalisation) with more detailed } \\
\text { documentation in the scale of } 1: 25 \\
000 \text { and locally at } 1: 10 \text { 000. } \\
\text { Sometimes it is necessary to correct } \\
\text { mapped areas according to the valley } \\
\text { network and contour lines } \\
\text { (Source: http://www.geology.cz) }\end{array}$ \\
\hline 2 & soil science & $\begin{array}{l}\text { Soil water } \\
\text { retention } \\
\text { capacity and } \\
\text { hydrological } \\
\text { soil groups } \\
\text { CR 50 }\end{array}$ & $\begin{array}{l}\text { Research Institute for } \\
\text { Soil and Water } \\
\text { Conservation } \\
\text { (VÚMOP) }\end{array}$ & $\begin{array}{l}\text { Digital soil maps differentiate areas } \\
\text { of classes of soil water retention } \\
\text { capacity and filtration coefficient. } \\
\text { Seamless maps are available at a } \\
\text { resolution corresponding to the scale } \\
\text { of } 1: 50 \text { 000 though they were } \\
\text { apparently constructed (before } \\
\text { generalisation) with more detailed } \\
\text { documentation in a scale of } 1: 5000 . \\
\text { Woodlands are omitted. (source: } \\
\text { http://www.vumop.cz/ }\end{array}$ \\
\hline \multicolumn{5}{|c|}{ Operational block } \\
\hline 3 & $\begin{array}{l}\text { Inland } \\
\text { transport } \\
\text { roads }\end{array}$ & Road map & $\begin{array}{l}\text { Directorate of Roads } \\
\text { and Motorways (RSD) }\end{array}$ & $\begin{array}{l}\text { Digital Road map presents roads in } \\
\text { layers of different road classes. }\end{array}$ \\
\hline 4 & topography & ZABAGED & $\begin{array}{l}\text { State Administration } \\
\text { of Land Surveying and } \\
\text { Cadastre (Č́UZK) }\end{array}$ & $\begin{array}{l}\text { Geodatabase ZABAGED in both in } \\
\text { raster and vector formats represents } \\
\text { a basic topographic maps of the } \\
\text { Czech Republic in the scale } 1: 10000\end{array}$ \\
\hline
\end{tabular}




\begin{tabular}{|c|c|c|c|c|}
\hline No. & $\begin{array}{l}\text { branch of } \\
\text { knowledge }\end{array}$ & $\begin{array}{l}\text { title of } \\
\text { geodata }\end{array}$ & administrator & \begin{tabular}{|l} 
data contents and method of \\
application
\end{tabular} \\
\hline \multicolumn{5}{|c|}{ Operational block } \\
\hline 5 & orientation & $\begin{array}{l}\text { coloured } \\
\text { ortophotomap }\end{array}$ & Cenia & $\begin{array}{l}\text { Continuously updated colour aerial } \\
\text { orthophotomap shows the current } \\
\text { situation of the territory. Data can be } \\
\text { retrieved from the map server. It } \\
\text { represents a resolution of about } 1 \mathrm{~m} \text {. }\end{array}$ \\
\hline 6 & geomorphology & $\begin{array}{l}\text { Digital } \\
\text { model of } \\
\text { relief of 4th } \\
\text { generation }\end{array}$ & ČÚZK & $\begin{array}{l}\text { The digital terrain model was } \\
\text { completed using lidar technology for } \\
\text { the total territory of the Czech } \\
\text { Republic. Its vertical resolution is a } \\
\text { few dms, horizontal less than } 5 \mathrm{~m} \text {. } \\
\text { Source: . http://www.cuzk.cz/ }\end{array}$ \\
\hline 7 & land use & $\begin{array}{l}\text { ZABAGED - } \\
\text { forests, } \\
\text { meadows, built- } \\
\text { up areas, } \\
\text { communications } \\
\text { and other }\end{array}$ & ČÚZK & $\begin{array}{l}\text { Individual classes of land use are } \\
\text { registered in the geodatabase } \\
\text { ZABAGED in separated data layers. } \\
\text { Layers of forest, meadows, arable } \\
\text { land and built-up areas are relevant } \\
\text { for scenarios. The data resolution } \\
\text { corresponds to the map scale } \\
1: 10000 \\
\text { Source http://www.cuzk.cz/ }\end{array}$ \\
\hline 8 & hydrology & $\begin{array}{l}\text { the water } \\
\text { management } \\
\text { map 50 }\end{array}$ & $\begin{array}{l}\text { T. G. Masaryk Water } \\
\text { Research } \\
\text { Institute (VÚV) }\end{array}$ & $\begin{array}{l}\text { The map shows the river network, } \\
\text { other water objects and watersheds } \\
\text { in the resolution of } 1: 50000 \text {. } \\
\text { Source: http://www.vuv.cz }\end{array}$ \\
\hline 9 & $\begin{array}{l}\text { Hydrometeor } \\
\text { ology }\end{array}$ & $\begin{array}{l}\text { Saturation } \\
\text { indicator }\end{array}$ & $\begin{array}{l}\text { Czech } \\
\text { Hydrometeorological } \\
\text { Institute (CHMU) }\end{array}$ & $\begin{array}{l}\text { The saturation indicator represents } \\
\text { an estimation of the current } \\
\text { saturation of the territory with water, } \\
\text { usually at } 8: 00 \text { a.m. local time. It can } \\
\text { also be generated during the day to } \\
\text { different hours repeatedly. It is } \\
\text { derived using a simple model of the } \\
\text { balance of rainfall, runoff and } \\
\text { evapotranspiration. Its main task is } \\
\text { the detection of potential risk of } \\
\text { flash floods development and } \\
\text { occurrence. } \\
\text { Source: ČHMÚ-http://hydro.ch- } \\
\text { mi.cz/hpps/main_rain.php?mt=ff } \\
\text { g }\end{array}$ \\
\hline 10 & $\begin{array}{l}\text { Administrati } \\
\text { ve division }\end{array}$ & $\begin{array}{l}\text { CS0_US_ } \\
\text { communes }\end{array}$ & $\begin{array}{l}\text { Czech Statistical } \\
\text { Office } \\
\text { (CSO) }\end{array}$ & $\begin{array}{l}\text { Digital map layer presents: } \\
\text { administrative limits of communities } \\
\text { on the territory of the Czech } \\
\text { Republic. } \\
\text { Source: database of Fire Rescue } \\
\text { Service of the Czech Republic (HZS } \\
\text { ČR) }\end{array}$ \\
\hline
\end{tabular}

Both procedure units are demonstrated on the example of a simulated accident on highway D1 (Fig. 1). 


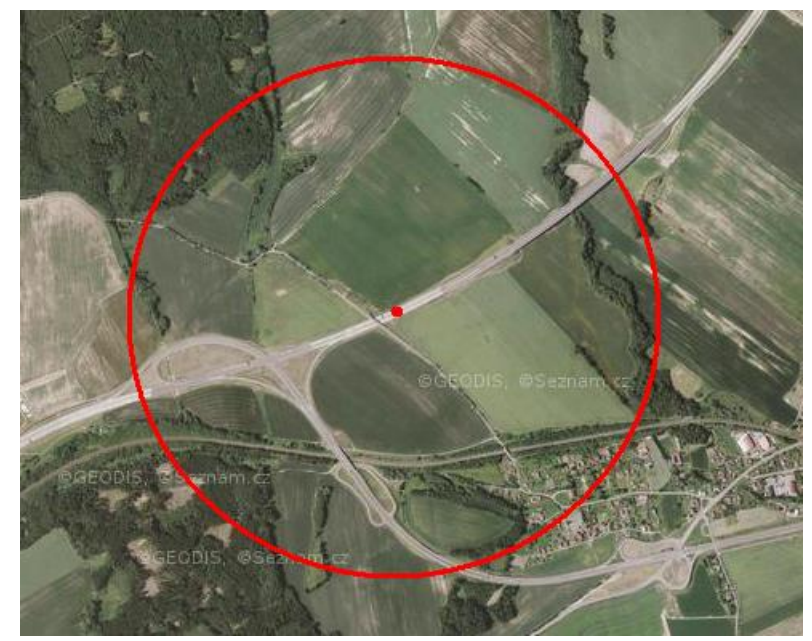

Fig. 1. Visualisation of the segment of the seamless colour ortophotomap surrounding the simulated accident on the D1 motorway at the $312^{\text {th }}$ kilometre from Prague. It shows the location of the event in the centre from a circle with a radius of $1000 \mathrm{~m}$

(Source: http://mapy.cz/letecka?x=17.7855914\&y=49.5958452\&z=16)

\subsection{Data processing}

A - the preparatory block of geo-data processing is focused on the classification of territorial units throughout the Czech Republic from the viewpoint of the expected behaviour of a liquid pollutant (with undifferentiated viscosity) and on the evaluation of the territory penetration level for the intervention technique. In terms of the movement of pollutants in the terrain and the possibility of stopping this movement, it is important whether the liquid substance will predominantly soak into the soil and geological environments, or whether it will dominantly flow down the surface or process infiltration into the ground and the downslope surface run-off will be more or less equally significant.

The tendency of soil cover to support liquids soaking from the surface, or conversely its resistance to liquid penetration may generally be derived from soil properties recorded on the map of soil water retention capacity of the Czech Republic at a scale of 1:50 000 and on a map of hydrological soil groups in the Czech Republic 1:50 000. The data are distributed by the data administrator - namely the Research Institute for Soil and Water Conservation (VÚMOP) - to customers in the ESRI shape file format at a resolution corresponding to a scale of 1:50 000, mainly by the layout of topographic map sheets of basic topographic maps of the Czech Republic at a scale of 1:50 000 (not required). The map of water retention capacity highlights the tiered possibility of soaking, or rather of runoff liquids according to the soil water regime (and, of course, the nature of the leaking substance). The interpreted map of water retention capacity of soils (according to Table 2) represents an intermediate stage for further data processing.

The evaluation of hydrological soil groups in terms of the risks of support, or seepage of liquid pollutant, can be done in analogy with the previous case, through expert assessment. It is convenient to implement it off-line for the entire territory of the Czech Republic already in the preparatory stage of the procedure for a possible case of similar incidents elsewhere in the country. 
Table 2

Targeted soil classification of the water retention capacity according to soil influence on the runoff of liquid pollutant ( $R$ - dominated by surface runoff, $\mathbf{I}$ - prevails infiltration, $\mathbf{N}$ - balanced ratio of infiltration and surface runoff)

\begin{tabular}{|l|c|c|c|l|}
\hline & & & & \\
\hline
\end{tabular}

However, the derived map itself tentatively indicates the behaviour of pollutants with regard to the long term soil moisture content and the soil's ability to absorb or 'repel' flowing harmful substances. In other words, 'the final water retention capacity reflects the average depth of soil profile and water content. They characterise the actual amount of water which the soil is capable of retaining'. The completed evaluation of soil water retention capacity in terms of risk of support, or prevention soaking of liquid pollutant, is a matter of expert assessment and can be done off-line.

The Map of hydrological soil groups based on the size of the infiltration coefficient of soil is based on grain composition of soils and their mechanical effect on the possibility of infiltration, or rather of liquid runoff. The content of the map 'Hydrological soil groups' (according to VÚMOP: Map and data products - hydrological characteristics) is specifically interpreted in the form of a map describing the anticipated character of the liquid pollutant runoff according to the hydrological soil groups. Conversion of the original map content is purposely oriented into three groups (Table 3) and the relevant maps in the GIS.

The integration of partial evaluations of the soil and geological environments forming a general overview of the expected behaviour of liquid pollutants in the potentially affected area runs through an overlay of partially interpreted maps in the raster format and completes combinations of letters. If in the three-digit combination is mostly 'I' the result should be marked "I" (the predominant process is the infiltration of liquid), if 'R' prevails - the surface runoff of liquid prevails) if ' $\mathrm{N}$ ' dominates - it results finally in ' $\mathrm{N}$ (neutral behaviour of liquids with a tendency of surface runoff), if all three letters are represented in the three-digit combination - ' $\mathrm{N}$ ' is the result. 
Table 3

Targeted soil classification of the stipulated hydrological groups according to their influence on the liquid pollutant runoff (the table of abbreviations - see Table 2).

\begin{tabular}{|c|c|c|c|c|}
\hline 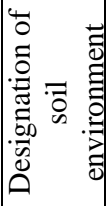 & $\begin{array}{l}a \\
\overline{0} \\
0 \\
0 \\
0 \\
0 \\
0 \\
0\end{array}$ & 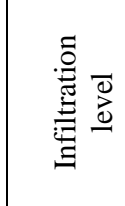 & 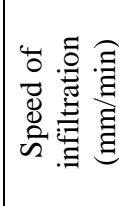 & Specific characteristics \\
\hline I & $\begin{array}{l}\text { Group } \\
\text { A }\end{array}$ & high & 0.20 & $\begin{array}{l}\text { it supports very well the infiltration of rainwater / pollutant } \\
\text { and causes a good penetrability of the terrain by the } \\
\text { intervention technique }\end{array}$ \\
\hline I & $\begin{array}{l}\text { Group } \\
\text { B }\end{array}$ & middle & $\begin{array}{l}0.10 \\
- \\
0.20 \\
\end{array}$ & $\begin{array}{l}\text { It supports well the infiltration of rainwater / pollutant and } \\
\text { also causes a good penetrability of terrain by the } \\
\text { intervention technique. }\end{array}$ \\
\hline $\mathrm{N}$ & $\begin{array}{l}\text { Group } \\
\text { C }\end{array}$ & low & $\begin{array}{c}0.05 \\
- \\
0.10\end{array}$ & $\begin{array}{l}\text { It supports the surface runoff of water / pollutant quite a lot, } \\
\text { which is sufficient for conditioned terrain penetrability }\end{array}$ \\
\hline $\mathrm{R}$ & $\begin{array}{l}\text { Group } \\
\text { D }\end{array}$ & $\begin{array}{l}\text { Very } \\
\text { low }\end{array}$ & $<.05$ & $\begin{array}{l}\text { it represents an almost impervious environment strongly } \\
\text { supporting surface runoff and causes poor penetrability for } \\
\text { intervention techniques }\end{array}$ \\
\hline
\end{tabular}

Table 4

Targeted classification of rocks according to their influence on runoff of liquid pollutants (the test area around Bělotín example).

\begin{tabular}{|c|c|c|}
\hline $\begin{array}{l}\text { Label of } \\
\text { geological } \\
\text { environment }\end{array}$ & $\begin{array}{c}\text { Purpose } \\
\text { characteristic }\end{array}$ & $\begin{array}{l}\text { Classification of rocks } \\
\text { (With numbers used in the picture/table of the geological map }\end{array}$ \\
\hline I & $\begin{array}{l}\text { Rocks and soils } \\
\text { insufficiently } \\
\text { supporting surface } \\
\text { runoff and } \\
\text { strongly supports } \\
\text { soaking }\end{array}$ & $\begin{array}{l}\text { deluvial sandy-loamy and clayic-loamy sediments (6) deluvial } \\
\text { loamy-stony sediments (7) glacifluvial sandy gravels (10), fluvial } \\
\text { sandy gravel terraces (13), loamy stony eluvium (15), Tertiary } \\
\text { sands and sandy gravels (16), calcareous sands (18) alluvial fans } \\
\text { (42) }\end{array}$ \\
\hline $\mathrm{N}$ & $\begin{array}{l}\text { Rock and soil } \\
\text { support in average } \\
\text { surface runoff as } \\
\text { well as soaking }\end{array}$ & $\begin{array}{l}\text { loess loam (8), picrites basalts, tuffs (29), conglomerates, } \\
\text { sandstones, mudstones (30), shales, siltstones, offals (33), offal } \\
\text { (34), assorted conglomerates (36) limestones (41), landslides } \\
(43)\end{array}$ \\
\hline $\mathrm{R}$ & $\begin{array}{l}\text { Rocks and soils } \\
\text { intensely } \\
\text { supporting surface } \\
\text { runoff and not } \\
\text { much soaking }\end{array}$ & $\begin{array}{l}\text { peat (2), fluvial sandy loam sediments (4) deluvial sandy loam } \\
\text { sediments (5) glacilacustrineclays (11), clay-loamy eluvium (14), } \\
\text { Tertiary calcareous clays (17), sandstones and claystones of } \\
\text { Ždánice-Hustopeče formation (19), claystones and silicites of } \\
\text { menilite formation (20), claystones of sub-menilite formation } \\
\text { (21), sandstones and conglomerates of Stráže type (22), gray } \\
\text { calcareous claystones and sandstones of Frydek strata (23), } \\
\text { calcareous claystones of Dub formation (24), claystone and } \\
\text { sandstones of Nemětice formation (26), calcareous claystones, } \\
\text { sandstones and conglomerates of Těšín-Hradiště formation(28). }\end{array}$ \\
\hline
\end{tabular}


The integrated output constitutes a derived character of the resulting pollutant behaviour. The procedure is performed in two alternatives: for a dry territory situation (Fig. 2 - left) and for the wet territory condition (Fig. 2 - right), depending on the nature of the topic water saturation of the area. This information is provided in cartographic form at a resolution of $1 \mathrm{~km}^{2}$ by CHMI on its website for the entire territory of the Czech Republic. In the case of water saturation of the area (wet situation), the value ' $N$ ' is changed to ' $\mathrm{R}$ '.
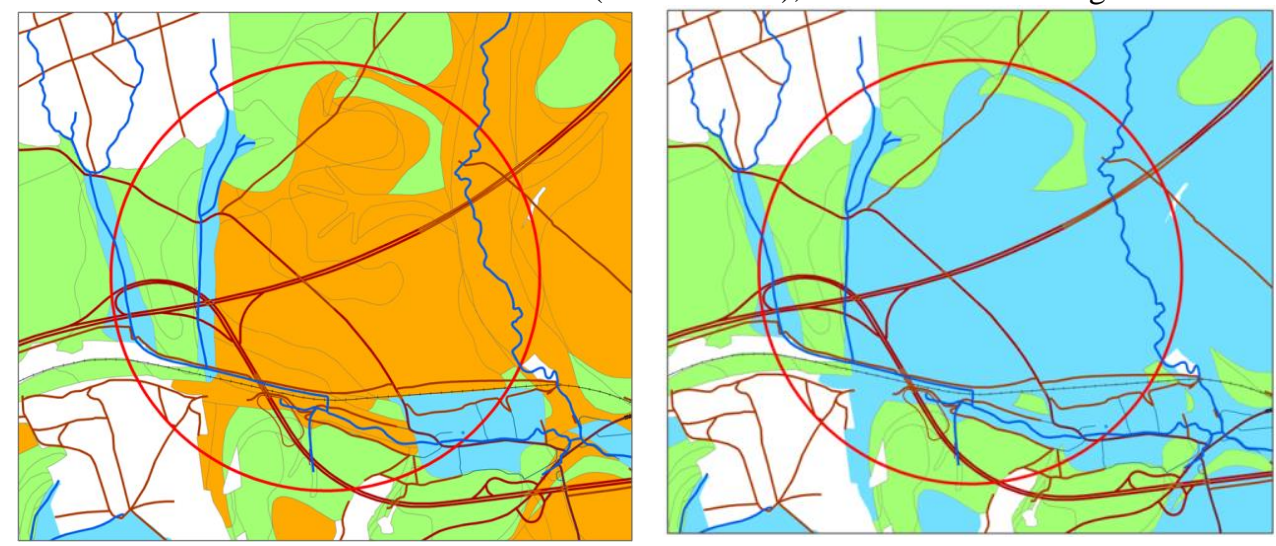

Fig. 2. Visualisation of areas with different behaviour of liquid pollutant under dry - left and under wet - right territory conditions (light blue - surface run-off; light green - soaking; orange -surface run-off; white - forests), the circle radius is 1000 m (Source: CGS, VÚMOP, ČÚZK).

The character of the movement of liquid pollutants in the environment is also affected by the slope gradient and surface roughness. The surface roughness varies during the seasons of the year and depends on the state of the vegetation cover. The agricultural plots show the most significant changes; it is not possible to ensure reliable information about the state of the surface in advance for any place in the state. The situation is different in the case of the slope. A currently available $4^{\text {th }}$ generation digital terrain model constructed on the base of aerial laser scanning has a horizontal resolution of app. $5 \mathrm{~m}$ for the entire territory of the Czech Republic. Its application is expected in the operating block of the procedure.

Operational block B is started by adopting the report of the accident stating its position. In the narrow space around the accident site in a digital terrain model, an estimated number of points are entered. Using the hydrological modelling in GIS, the immediately possible routes of runoff toward the nearest surface water receptors are derived (Fig. 3). The identification of several possible routes may cause scattering of attention disaster staff, which sends an intervention unit (or better more units) to the site of the incident. Meanwhile, the incident commander already ascertains on site which of the modelled pollutant runoff routes is true. This will be then the focus of the intervention unit with the aim to eliminate the impacts of the accident. Emergency units are primarily tasked with stopping the spread of liquid toxic pollutants. They cannot do it in any place, but only in places accessible to the technique. The motion of the technique is limited not only by the natural parameters of the terrain (high slope, watercourses, long-soaked sites or currently waterlogged places with limited infiltration of liquids) but also by anthropogenic objects and by the different forms of land use. 


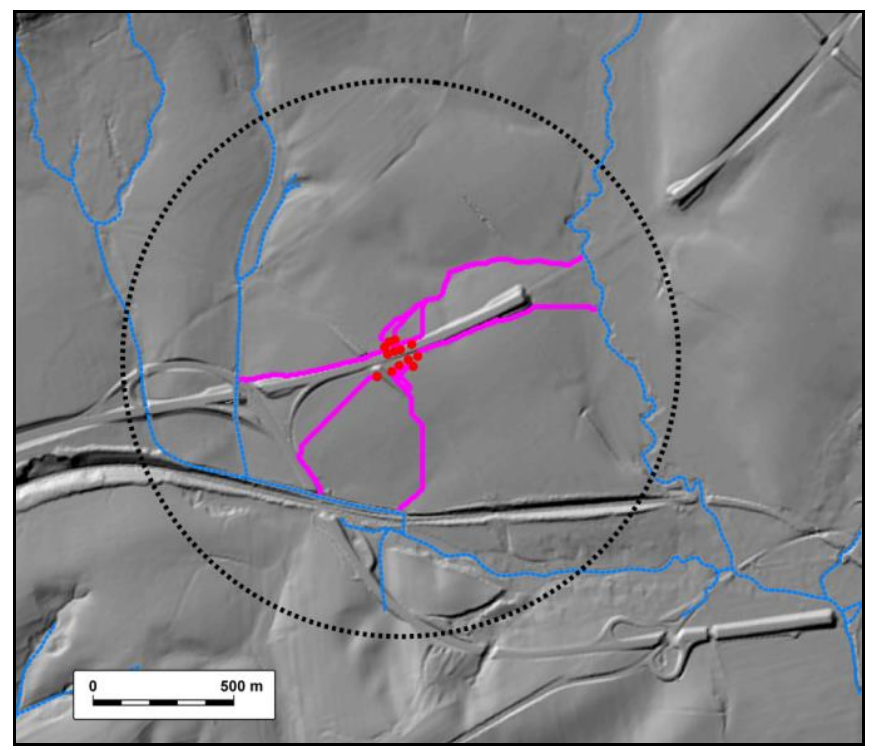

Fig. 3. Example of an operative search of possible outflow routes of liquid pollutants (in purple) downslope from the accident site (red dots located around the accident site) within a circle with a radius of $1000 \mathrm{~m}$ around the crash site showing watercourses (in blue) as well (Source: ĆÚZK).

The main task is to prevent direct contamination of watercourses by moving liquid pollutants. "Key points" must be identified (localities where the route of pollutant changes one type of environment to another - e.g. sites with domination infiltration or surface runoff).

Depending on the environment in which the movement of pollutants takes place, it is necessary to select a form of intervention (e.g. damming of routes in areas where the surface runoff dominates and not allowing its entry into the environment with a predominance of soaking, which would result in the contamination of ground waters or the draining fluid if it has already penetrated to the infiltration area). If the water courses are surrounded by forest, which is impervious to the technique, it is necessary to prevent the entry of liquid pollutants into the forest. Key points are thus determined either by the data analysis in GIS such as the intersections of potential routes of the pollutant movement together with the boundaries of the different types of the environments (depending on the nature of the soil and geological structure) and the forest limit. It is much easier to create a new point shape file within an on-screen operation of the eligible disaster staff personnel. The intervention of the field emergency unit must then be directed over these points into a higher altitude. In the case of this simulated accident 5 key points to 5 routes of the anticipated movement of liquid pollutant were identified. Point no. 1 is at the place where section with a predominant infiltration passes to a section of a dominant surface runoff (Fig. 4 - left). The points no. 2, 3, 4 and 5 are on the edge of the forest, through which a watercourse passes affected by contamination (Fig. 4 - right).

It is necessary to find out the applicable access routes for the intervention technique to these five key points operationally. It is also necessary to take into account all the supposed barriers to technique movement and to use safe routes of access. The slope gradient plays an important role. 

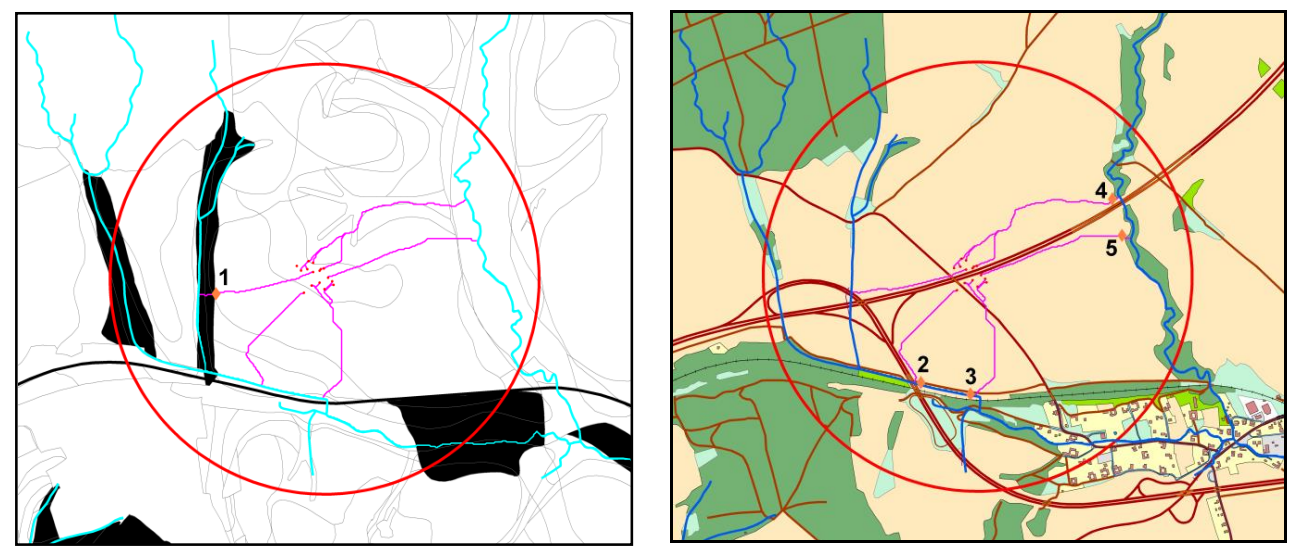

Fig. 4. The distribution of key points on the routes of anticipated flow of liquid pollutant towards the water receptors (left - a key point no. 1 on the physically different types of the natural environment for the movement of pollutants, right - key points 2,3 on the direct contact with the potential water receptor, 4 and 5 on the edge of the forest area with the potential water receptor inside).

There is no uniform standard for reliable passage of terrain by different types of intervention techniques and success usually depends on the skills of the driver and the current state of the technique. At least in general, the areas in which intervention technique should be avoided can be designated. These can be, in the case of a slope, represented by a gradient above $15^{\circ}$ under dry area conditions (Fig. 5 - left) and $7^{\circ}$ under wet conditions (Fig. 5 - right). Areas of such critical gradients can be derived from the digital terrain model.
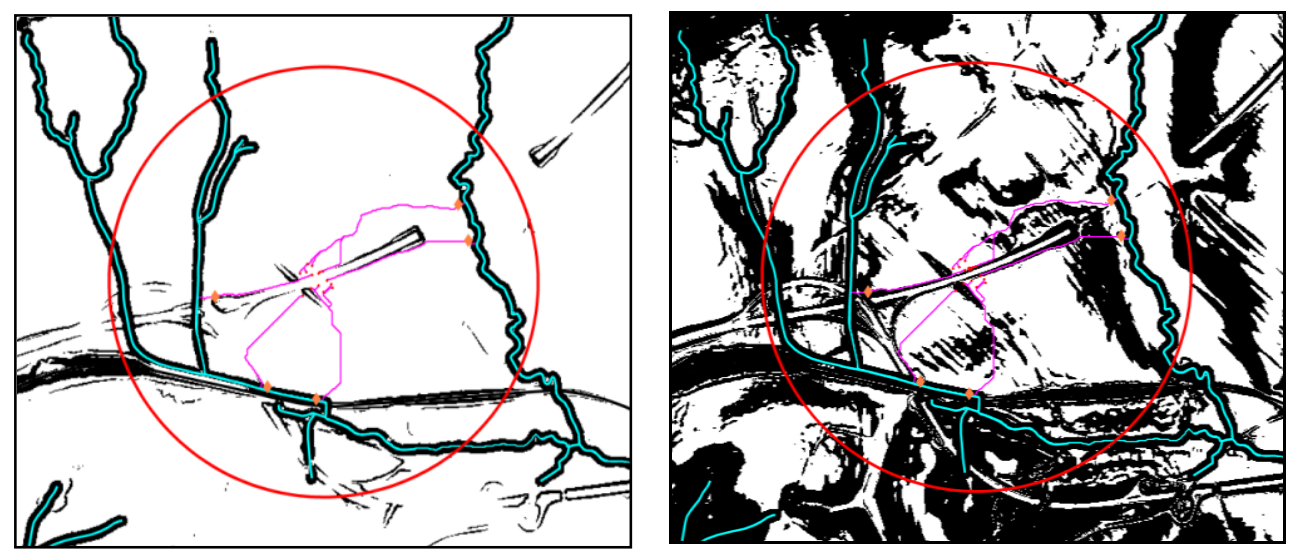

Fig. 5. Slope gradient as a barrier for the access of intervention techniques (left - inclination over $15^{\circ}$ under dry conditions; right - slope inclination above $7^{\circ}$ under wet conditions).

Another obstacle to the movement of intervention techniques arises from the nature of the soil and the geological environment. This environment becomes an obstacle when rainwater infiltration is not allowed (because of long-term or momentary saturation with water). Therefore the areas where different features affecting the movement of liquid 
pollutants were identified in the preliminary block can be applied. The areas of the dominant surface runoff of the liquid pollutant in dry and wet conditions represent the barrier. Another type of barrier is rivers and some forms of land use (buildings, walls, fenced gardens, railway, forest, wetlands, etc.) depending on the particular area (see e.g. Hasnat, Islam \& Hadiuzzaman, 2018). Through the summation of data layers of individual barriers it is possible to gain an integral layer of barriers to the access of the emergency units. Such a layer may be prepared already in the initial preparatory block for the entire country. Due to the demanding character of the countrywide processing of huge data files, and the relative simplicity of available data interpretation - both pre-elaborated in a preparatory block (character movement of liquid pollutants) and taken from available public sources (DTM, river network, land use), this data can be processed only for the area around the site of the accident after reporting its position. It is important to know the course of existing roads passable for the intervention technique in the terrain (Fig. 6).
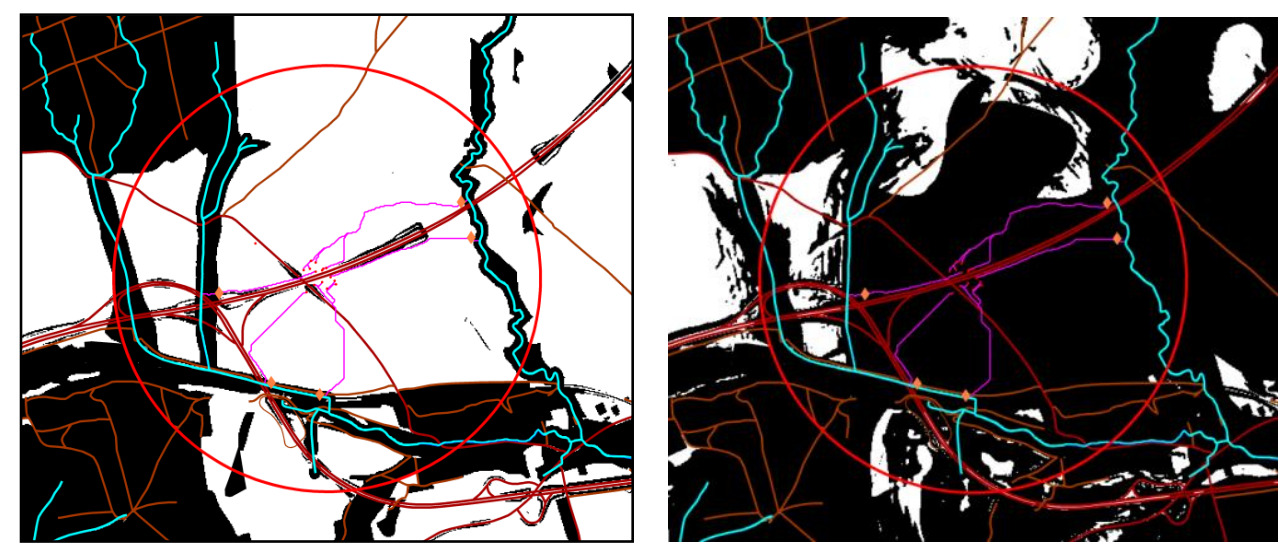

Fig. 6. Territorial distribution of all identified types of barriers for assessment of intervention teams in the territory towards the key points on the routes of liquid pollutant flow (left - under dry conditions, right - under wet condition) with presentation of the existing road network.

Searching for the optimal route access by the intervention technique to key points is done by standard tools in ArcGIS technology (version 10.2, Cost Distance and the Cost Path in Spatial Analyst). The input data layers to this procedure are:

1. The layer of barriers to the intervention technique access (with alternatives for dry or wet) conditions converted into binary form (masks),

2. The layer of the road network (on which the technique can come as close as possible to the critical points),

3. The layer of critical points which are the localities of the last chance for adequate intervention for prevention of the liquid pollutant spread (Fig. 7).

It is evident from Fig. 6-right that under wet conditions (with long-standing and simultaneously instantaneous water saturation of soil and geological environment after the previous precipitation period) the accessibility for the intervention technique is at high risk, and the emergency unit has to be aware of this. The problem can then be solved by deploying special techniques (belt, air), or pedestrian access for the intervention team. For an alternative under dry conditions, finding optimal routes for the intervention technique is possible using ArcGIS tools. The incident commander at the site then directs the operating 
units on the routes along which is the liquid pollutant moves (Fig. 7). According to the cadastral maps and the actual flow of liquid pollutant, the incident commander determines to which municipalities a warning against the threat of direct contamination by the flowing harmful substances, or indirectly by contaminated water in the water recipient (if it fails to stop the dripping) will be sent.

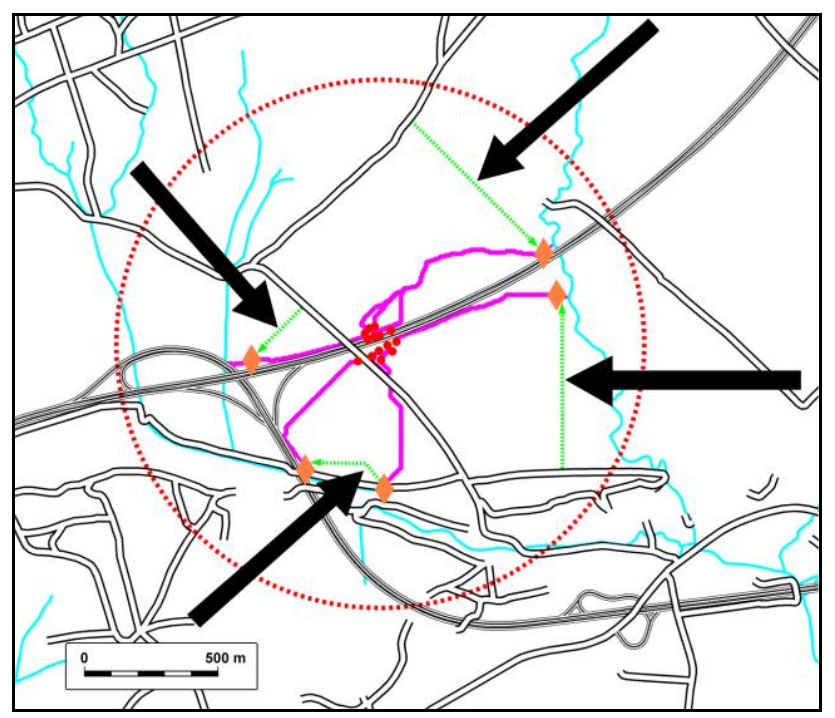

Fig. 7. Optimal access routes from existing road network (in green) avoiding all types of barriers to key points on lines of expected flow of liquid pollutant for intervention teams searched operationally using ArcGIS tools.

\section{CONCLUSIONS}

The demonstrated procedure of selected steps of a disaster team is based solely on publicly available geodata in the Czech Republic, their interpretation and processing. The division is into two working units: the preparatory block and the operational block, and it is necessary to be able to timely and effectively counter the threat of contamination of waterways by toxic liquid that leaked into the environment after an accident on the road, at any point on the road network. This data should be permanently available for the disaster staff - its workplace GIS (both national and regional), or unrestricted access should be organised. According to current Czech legislation it is possible. The preparatory block is the most time-consuming - it deals with the qualified estimation of the movement character of liquid pollutants in the area and also the penetrability of the terrain for intervention techniques with regard to the soil and geological environment for two alternatives: under dry and wet conditions. Such data layer should be compiled and available for the entire country. Due to the nature of the data, however, it is applicable only in case of an accident outside of large forest units (necessary soil data are missing here).

The operational block uses pre-processed data from the preparatory block and operatively applies them to the nearby site of the accident with regard to the current state of saturation of the territory with water, which affects both the character of the movement of the liquid pollutant and the area penetrability for the intervention technology. Integrated 
data processing in order to optimise the intervention (choice of methods of intervention and their location) takes a matter of a few minutes. The intervention unit will be sent to the preselected sites and then operatively directed after being found on the sitethrough which the toxic liquid moves. Like this, the units can choose the method of action (draining, damming drainage), and the place of intervention with regard to the type and accessibility for the technique.

\section{ACKNOWLEDGEMENT}

This work was supported by the project "Disaster management support scenarios using geoinformation technologies" [No VG20132015106], programme Safety Research promoted by Ministry of Interior, Czech Republic; by VSB-Technical University of Ostrava, Faculty of Mining and Geology, Department of Geoinformatics, 17. Listopadu 2172/15, CZ-70800 Ostrava-Poruba, Czech Republic.

\section{R E F E R E N C ES}

Bernatík, A., 2006. Prevention of major accidents II. Ostrava, Association of Fire and Security Engineering with headquarters at VŠB (Prevence závažných havárií II. Ostrava, Sdružení požárního a bezpečnostního inženýrství se sídlem VŠB) - Technická univerzita Ostrava.

Bubbico, R., Di Cave, S. \& Mazzarotta, B., 2004. Risk analysis for road and rail transport of hazardous materials: a GIS approach. Journal of Loss Prevention in the Process Industries, 17 (6), 483-488.

Burns, W. J. and Slovic, P., 2012. Risk perception and behaviours: anticipating and responding to crises. Risk Analysis, 32 (3), 579-82.

Cadar, R. D., Boitor, M. R. \& Dumitrescu, M., 2017. Effects of traffic volumes on accidents: The case of Romania's national roads. Geographia Technica, 12 (2), 20-29.

De Dominics, S., et al., 2015. We are at risk, and so what? Place attachment, environmental risk perceptions and preventive coping behaviours. Journal of Environmental Psychology, 43 (1), 6678.

De Haag, P. U. \& Ale, B.J.M., 2005. Guidelines for quantitative risk assessment (Purple book). Publication Series on Dangerous Substances (PGS 3). Guidelines for quantitative risk assessment. Ministerie van Binnenlandse Zaken en Koninkrijkrelaties/Ministerie van Verkeer en Waterstaat, The Hague.

De Silva, F.N. \& Eglese, R W., 2000. Integrating simulation modelling and GIS: spatial decision support systems for evacuation planning. Journal of the Operational Research Society, 51 (4), 423-430.

Diamantidis, D., Zuccarelli, F. \& Westhäuser, A., 2000. Safety of long railway tunnels. Reliability Engineering \& System Safety, 67 (2), 135-145.

Fabiano, B., et al., 2002. A framework for risk assessment and decision making strategies in dangerous food transportation. Journal of Hazardous Materials, 93 (1), 1-15.

Fujiki, K. \& Renard, F., 2018. A geographic analysis of post-disaster social impacts on a municipal scale - A case study of a potential major flood in the Paris region (France). Geographia Technica, 13, (2), 31-51.

Goerlandt, F. \& Montewka, J., 2015. Maritime transportation risk analysis: Review and analysis in light of some foundational issues. Reliability Engineering \& System Safety, 138 (6), 115-134.

Hasnat, M. M., Islam, M. R. \& Hadiuzzaman, M., 2018. Emergency response during disastrous situation in densely populated urban areas: A GIS based approach. Geographia Technica, 13 (2), 74-88. 
Høj, N. P. \& Kröger, W., 2002. Risk analyses of transportation on road and railway from a European Perspective. Safety Science, 40 (1-4), 337-357.

Huang, B., 2004. A GIS based route planning for hazardous material transportation. Journal of Environmental Informatics. 8 (1), 49-57.

Chudová, D. \& Blažková, K., 2007. Transport of hazardous substances from the point of view of emergency planning of the area Ostrava. (Přeprava nebezpečných látek z pohledu havarijního plánování území. Ostrava, Sborník vědeckých prací Vysoké školy báňské) - Technické univerzity Ostrava. LIII(1): řada bezpečnostní inženýrství, pp. 9-14.

Ivan, K. \& Haidu, I., 2012. The spatio-temporal distribution of road accidents in Cluj-Napoca. Geographia Technica, 7(2), 32-38.

Kolejka, J., 2010. Digital geographic data utilization in simulating toxic road accident. Riscuri si catastrofe, 8 (1), 11-24.

Kolejka, J., Rapant, P., et al., 2015. Scenarios to support crisis management with geoinformation technologies (Scénáře podpory krizového řízení geoinformačními technologiemi), 1st ed., Brno, Soliton.

Kolejka, J., Rapant, P. \& Zapletalová, J. 2016. The GIS support to measures on the ground in case of leakage of liquid pollutant on the road. In: Proceedings of the $23^{\text {rd }}$ Central European Conference. Central Europe Area in View of Current Geography. Masarykova univerzita, Brno, pp. 179-190.

Krejčí, L. \& Bambušek, M., 2012. Risky transport of dangerous goods by road in the Czech Republic (Rizikovost přepravy nebezpečných věcí silniční dopravou v ČR). Available at:. http://pernerscontacts.upce.cz/27_2012/Krejci.pdf.

Maschio, G., et al., 2009. A GIS tool for the emergency management of terrorist actions in the transport of hazardous substance. Journal of Loss Prevention in the Process Industries, 22 (5), 625-633.

Nicolet-Monnier, M. \& Gheorghe, A., 1996. Quantitative Risk Assessment of Hazardous Materials Transport Systems: Rail, Road, Pipelines and Ship. Springer Science \& Business Media.

Raemdonck, K., Macharis, C. \& Mairesse, O., 2013. Risk analysis system for the transport of hazardous materials. Journal of Safety Research, 45 (1), 55-63.

Sobotka, P., 2015. Accident information on the roads of the Czech Republic per year 2014 (Informace o nehodovosti na pozemních komunikacích České republiky za rok 2014). 19 p., Available at: www.policie.cz/soubor/2014-12-informace-pdf.aspx.

Ştefănescu, L., Botezan, C. \& Crăciun, I., 2018. Vulnerability analysis for two accident scenarios at an upper-tier Seveso establishment in Romania. Geographia Technica, 13 (1), 109-118.

Tůma, J., 2000. Catastrophic Techniques of 20th Century Fears (Katastrofy techniky děsící 20. Století). Praha, Academia.

Verma, M. \& Verter, V., 2007. Railroad transportation of dangerous goods: Population exposure to airborne toxins. Computers \& Operations Research, 34 (5), 1287-1303.

Vonásek, V. \& Lukeš, P. (eds.), 2015. Statistical Yearbook 2014 Czech Republic. Fire protection, Integrated Rescue System, Fire \&Rescue Service of the Czech Republic. Praha, Ministerstvo vnitra, Generální ředitelství Hasičského záchranného sboru.

Zhang, J., Hodgson, J. \& Erkut, E., 2000. Using GIS to assess the risks of hazardous materials transport in networks. European Journal of Operational Research, 121 (2), 316-329. 